\title{
Temperature Effect on Lime Powder-Added Geopolymer Concrete
}

\author{
Sandeep L. Hake $\mathbb{D}^{1}{ }^{1}$ R. M. Damgir, ${ }^{2}$ and S. V. Patankar ${ }^{3}$ \\ ${ }^{1}$ Dr. V. V. P. College of Engineering, Ahmednagar, Maharashtra, India \\ ${ }^{2}$ Civil Engineering Department, Government College of Engineering, Aurangabad, India \\ ${ }^{3}$ S.R.E.S. College of Engineering, Kopargaon, Ahmednagar, Maharashtra, India \\ Correspondence should be addressed to Sandeep L. Hake; drsandeephake@gmail.com
}

Received 8 August 2017; Revised 3 January 2018; Accepted 9 January 2018; Published 28 February 2018

Academic Editor: Arnaud Perrot

Copyright (c) 2018 Sandeep L. Hake et al. This is an open access article distributed under the Creative Commons Attribution License, which permits unrestricted use, distribution, and reproduction in any medium, provided the original work is properly cited.

\begin{abstract}
The need for concrete increases with rapid development in the field of infrastructure because of the increased use of cementing material of concrete. The production of concrete is unsafe to the earth. Consequently, there is a need to discover new binding material with cementing properties. Fly ash debris is wastage of thermal power plants and acquires hectares of land for the dumping reason. This paper concentrates on development of alternative binding material in the field of construction. The fly ashbased geopolymer concrete is a better option, but it needs heat curing for the polymerization. The use of lime powder in the geopolymer concrete gives better result without heat curing. The experiment depends on the characteristics of daylight curing and impact of temperature in controlled oven curing. The M30 grade geopolymer concrete plans with the addition of lime powder. The addition of lime powder is changed by $0 \%, 5 \%, 10 \%, 15 \%, 20 \%$, and $25 \%$. The compressive strength increases with addition of lime powder, but in the cases of $20 \%$ and $25 \%$, the workability gets hamper. The study also deals with temperature variations when oven cured for $35^{\circ} \mathrm{C}, 40^{\circ} \mathrm{C}, 50^{\circ} \mathrm{C}$, and $60^{\circ} \mathrm{C}$ hence assessed.
\end{abstract}

\section{Introduction}

Concrete, as a noteworthy development material, is being utilized at a regularly expanding rate all around the globe. The cement is right now used in ordinary Portland concrete, which brings about a gigantic worldwide bond industry. Consistently, the creation of OPC is expanding with the expanding interest of development. Hence, the carbon dioxide discharge rate increases step by step into the air. One ton of carbon dioxide is transmitted into the air with the generation of one ton of Portland cement. The ozonedepleting substance emanation from the creation of Portland concrete is around 1.35 billion tons yearly, which is around $7 \%$ of the aggregate ozone-depleting substance outflow [1] (Patankar 2013). On the other way, fly ash is the waste material of coal-based thermal power plants, available abundantly, but creates a disposal problem. Several hectares of agricultural land are acquired by the thermal power plant for the disposal of fly ash. As it is light in weight and flies easily, it creates health problems like asthma and bronchitis.
Now, the challenge amongst the researchers is to find an appropriate alternative for eliminating the environmental hazards caused by the production of cement. A very prominent research by Davidovitts in 1978 was the invention of geopolymer concrete which was a cement-free concrete. This attracted a lot of attention where fly ash is replaced by cement for $100 \%$. It had its own identity and left remarkable impressions in the research studies. Geopolymer exhibits similar properties to that of conventional concrete; the only difference is that it is being $100 \%$ cement free. But challenging human tendency of having blind faith for years over cement for its strength and durability is an uprising challenge. Building this faith and trust for the use of geopolymer concrete over conventional concrete is a huge task and requires testing of geopolymer concrete against conventional concrete. Not only can the elimination of $\mathrm{CO}_{2}$ emission be avoided, but also there are lot many reasons for geopolymer concrete to be eco-friendly. The most prolific reason for use of fly ash is its dumping issue and its minimum use. Previous investigation made on geopolymer 
concrete reveals that good strength is achieved when curing is done at elevated temperature limiting its application on site. With an addition and replacement of optimum percentage of lime and cement, respectively, an additional amount of heat will be produced; when mixed with water, the reaction being exothermic can be used as an alternative for the elevated curing temperatures, thereby achieving the desired strength at normal room temperature and by wet curing giving it a wide scope and various practical applications and uses.

\section{Literature Review}

Dutta and Ghosh [2] studied that the pore sizes get a reduction after addition of limestone dust into the geopolymer paste sample. This phenomenon influences water absorption and compressive strength. Incorporation of limestone dust up to $15 \%$ increases the compressive strength of paste specimens about $44 \%$. The reduction in compressive strength due to lower curing temperature may be compensated by incorporation of calcium compound which can accelerate the rate of polymerization even at low temperature. Hake et al. [3] reported that the cement production generated carbon dioxide, which pollutes the atmosphere. The thermal industry produces a waste called fly ash which is simply dumped on the earth, which occupies larger areas. The waste water from the chemical industries is discharged into the ground which contaminates ground water. By producing geopolymer concrete, all the above-mentioned issues shall be solved by rearranging them. Waste fly ash from thermal industry + waste water from chemical refineries= geopolymer concrete. Further, the use of fly ash as a value-added material as in the case of geopolymer concrete reduces the consumption of cement. Reduction of cement usage will reduce the production of cement which in turn cut the $\mathrm{CO}_{2}$ emissions. Many researchers have worked on the development of geopolymer cement and concrete for the past ten years. The present work deals with the result of the experimental investigation carried out on geopolymer concrete using processed and unprocessed fly ash with sodium silicate and sodium hydroxide. The study analyses the effect of processed and unprocessed fly ash on compressive strength and split tensile strength for different temperatures. To study the effect of different types of processed and unprocessed fly ash, we use processed fly ash such as P60, P80, and P100 from Dirk India Pvt. Ltd. and unprocessed fly ash from different cities such as Bhusawal, Nashik, and Beed. In this paper, the effect of the alkaline solution on different fly ash is investigated. Namagga and Atadero [4] investigated that the replacement of high-lime fly ash in concrete generally increases the ultimate strength of concrete. It is probable that even higher percentile replacements of cement would still be able to provide the same compressive strength as no fly ash concrete. Replacement of cement with high-lime fly ash reduces the rate of strength development/gain beyond the optimal limits obtained for $25-35 \%$ fly ash mixes. More air entrained admixture is required for increasing amounts of fly ash used. Vijaya Rangan [5] stated that the elastic properties of hardened geopolymer concrete and the behavior and strength of reinforced geopolymer concrete structural members are
TABle 1: Chemical composition of materials.

\begin{tabular}{lcc}
\hline Chemical composition & Fly ash (\%) & Lime (\%) \\
\hline $\mathrm{SiO}_{2}$ & 57.30 & 3.92 \\
$\mathrm{Al}_{2} \mathrm{O}_{3}$ & 27.13 & 2.74 \\
$\mathrm{Fe}_{2} \mathrm{O}_{3}$ & 8.06 & 0.38 \\
$\mathrm{MgO}$ & 2.13 & 0.28 \\
$\mathrm{SO}_{3}$ & 1.06 & - \\
$\mathrm{Na}_{2} \mathrm{O}$ & 0.73 & - \\
$\mathrm{CaO}$ & 0.03 & 51.01 \\
$\mathrm{LOI}$ & 1.60 & 41.56 \\
$\mathrm{~K}_{2} \mathrm{O}$ & - & 0.04 \\
$\mathrm{TiO}_{2}$ & - & 0.09 \\
\hline
\end{tabular}

similar to those observed in the case of Portland cement concrete. Heat-cured low-calcium fly ash-based geopolymer concrete also shows excellent resistance to sulfate attack and fire, good acid resistance, low creep, and suffers very little drying shrinkage. Geopolymer concrete has several economic benefits. Bondar [6] investigated that geopolymer concrete can be produced with the same cost of OPC concrete and comparable properties. Geopolymer concrete develops moderate to high mechanical strength with a high modulus of elasticity and shrinkage much lower than that of OPC. Geopolymer concrete manufacture is liable to reduce $\mathrm{CO}_{2}$ emission as compared to OPC production. Vora and Dave [7] investigated that the compressive strength of the geopolymer concrete increases with the increase of concentration in terms of molarity of sodium hydroxide. The ratio of alkaline liquid to fly ash by mass does not affect the compressive strength of the geopolymer concrete. The sodium silicate to sodium hydroxide ratio by mass equal to 2 has resulted into the higher compressive strength as compared to the ratio of 2.5 for the geopolymer concrete. The workability of the geopolymer concrete in the fresh state increases with the increase of extra water added to the mix. The compressive strength of the geopolymer concrete decreases with the increase in the ratio of water to geopolymer solids by mass. The increase in the curing temperature in the range of $60^{\circ} \mathrm{C}-90^{\circ} \mathrm{C}$ also increases the compressive strength of the geopolymer concrete.

\section{Materials Used}

3.1. Fly Ash. Fly ash used in this study is low-calcium class F-processed fly ash from Dirk India Private Limited under the name of the product POZZOCRETE 60. The chemical compositions of the fly ash used along with the specifications are given in Table 1 . The specific gravity of the fly ash used is 2.26. The residue of fly ash retained on $45 \mu \mathrm{m}$ IS sieve was reported as $16.84 \%$. The fineness of the fly ash by Blen's method is $360 \mathrm{~m}^{2} / \mathrm{kg}$.

3.2. Alkaline Solution. The alkaline liquid used was a combination of sodium hydroxide and sodium silicate solution. Sodium hydroxide $(\mathrm{NaOH})$ in flakes form with $98 \%$ purity purchased from the local chemical supplier was used, and 
sodium silicate solution $\left(\mathrm{NaO}=16.84 \%, \mathrm{SiO}_{2}=35.01 \%\right.$, and water $=46.37 \%$ by mass) was used as the alkaline liquid. Sodium hydroxide solution is prepared by dissolving the flakes in water. Tap water available in the laboratory was used to prepare $\mathrm{NaOH}$ solution. The activator solution was prepared at least one day prior to its use. Molarity of the solution was $16 \mathrm{M}$.

3.3. Aggregates. Locally available $12.5 \mathrm{~mm}$ and $20 \mathrm{~mm}$ crushed aggregates are used as coarse aggregates having specific gravity 2.65. Locally available river sand is used as fine aggregate in the concrete mixes having specific gravity 2.5 and of Zone-I conforming IS specifications.

3.4. Lime. The limestone dust is a solid composite having a specific gravity of 2.7 and a bulk density of $1425 \mathrm{~kg} / \mathrm{m}^{3}$. It has an average particle size of 25 microns while particle size varies between $10 \mu$ and $70 \mu$. Chemical compositions of the fly ash used along with the specifications are given in Table 1 .

\section{Experimental Work}

The concrete cubes of size $150 \times 150 \times 150 \mathrm{~mm}$ were cast for trial mixes M30 grade for checking the workability slump cone test performed. In the geopolymer concrete, the alkaline activators such as sodium hydroxide and sodium silicate were used. The proportionate ratio of the alkaline solution is taken as 2.5. The experimental work evaluation of the optimum percentage of lime addition has to be worked out. For the same, cubes are to be cast for $5 \%, 10 \%, 15 \%, 20 \%$, and $25 \%$ of lime addition, whereas lime percentage is by weight to that of fly ash. Initially, temperature and testing age are kept constant, and curing hours are varied such as $06 \mathrm{hrs}, 12 \mathrm{hrs}, 18 \mathrm{hrs}$, and $24 \mathrm{hrs}$. In this case, the optimized curing hours were acquired; by using this, the degree of heating ranging from $40^{\circ} \mathrm{C}$ to $120^{\circ} \mathrm{C}$ at an interval of $10^{\circ} \mathrm{C}$ for oven curing was obtained. The concrete cubes were cast and cured at normal room temperature to know their characteristic strength as well. After evaluating the optimum curing hours, rest period and temperature beams and cylinders were cast for the evaluation of flexural and split tensile strength of lime-added fly ash-based geopolymer concrete.

4.1. Percentage of Lime Addition (M30). The specimens were cast of size $150 \mathrm{~mm} \times 150 \mathrm{~mm} \times 150 \mathrm{~mm}$ of grade M30 having alkaline solution ratio as 2.5. The concrete cubes were cured at $90^{\circ} \mathrm{C}$ in an oven for $24 \mathrm{hrs}$ with addition of varied lime percentages by weight of fly ash. After the completion of the defined curing time, the specimens were kept at normal room temperature with a rest period of 07 days. The specimens were tested for compression on a compression testing machine of capacity $2000 \mathrm{KN}$ to know the optimum percentage of lime addition and to study its effect on the strength of geopolymer concrete.

Figure 1 represents the variation in the strength of geopolymer concrete of grade M30 with the addition of lime percentage cured for 24 hours at a temperature of $90^{\circ} \mathrm{C}$.

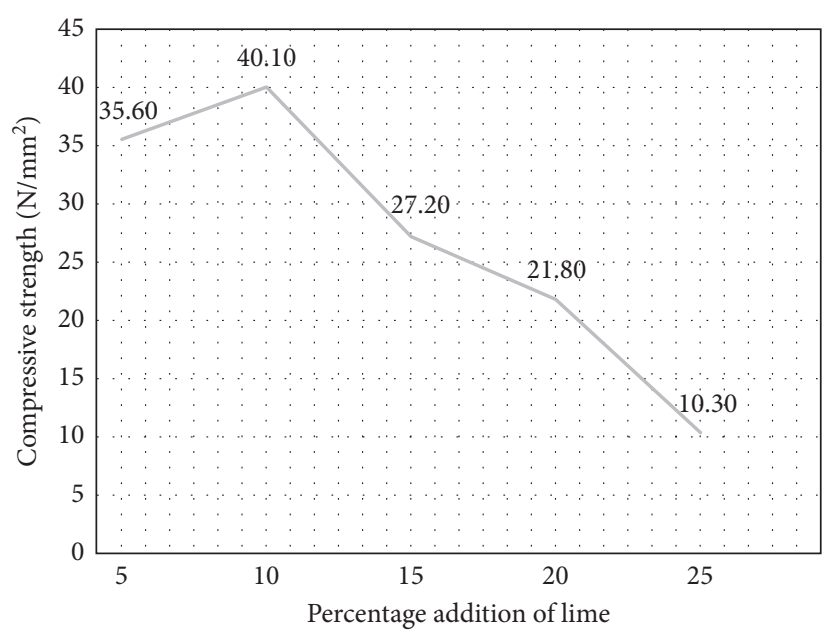

Figure 1: Percentage addition of lime powder in GPC oven cured at $90^{\circ} \mathrm{C}$.

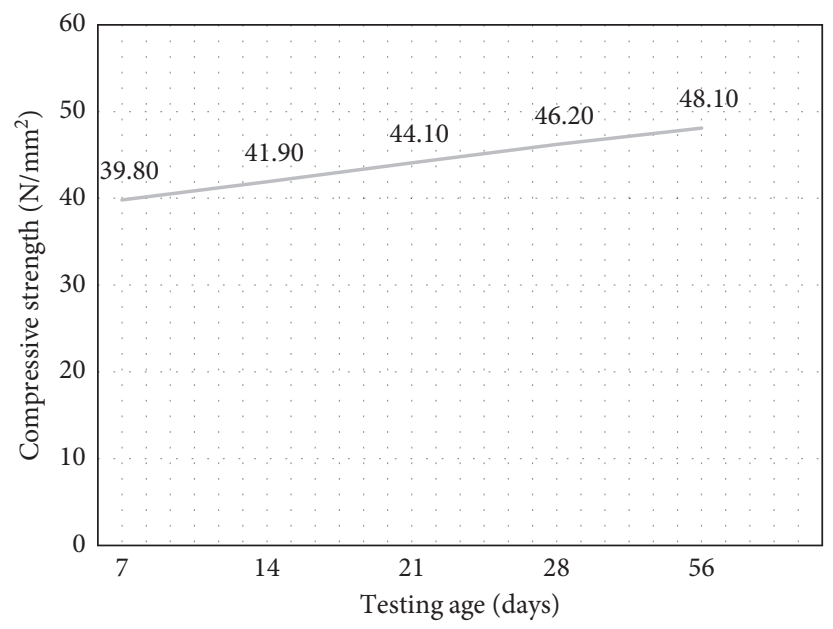

FIGURE 2: Effect of testing age on geopolymer concrete with oven curing.

The rest period for the cured specimens was 07 days. The maximum compressive strength was achieved with an addition of $10 \%$ of lime. Thus, the optimum percentage of lime addition observed here is $10 \%$.

4.2. Effect of Rest Period. The specimens were cast of size $150 \mathrm{~mm} \times 150 \mathrm{~mm} \times 150 \mathrm{~mm}$ of grade M30 having alkaline solution ratio as 2.5 and were cured at $90^{\circ} \mathrm{C}$ in an oven for $24 \mathrm{hrs}$ with the addition of optimized lime percentages (10\%). The lime percentages were calculated in accordance with the weight of fly ash. After the completion of the defined curing time, these specimens were kept at normal room temperature with a rest period or testing age of 07,14 , 21,28 , and 56 days. The specimens were tested after testing age to know the effect of the rest period on the strength of GPC with lime addition into geopolymer concrete.

Figure 2 represents the increase in the strength of geopolymer concrete of grade M30 with the increase in the rest period at a temperature of $90^{\circ} \mathrm{C}$. The maximum compressive 


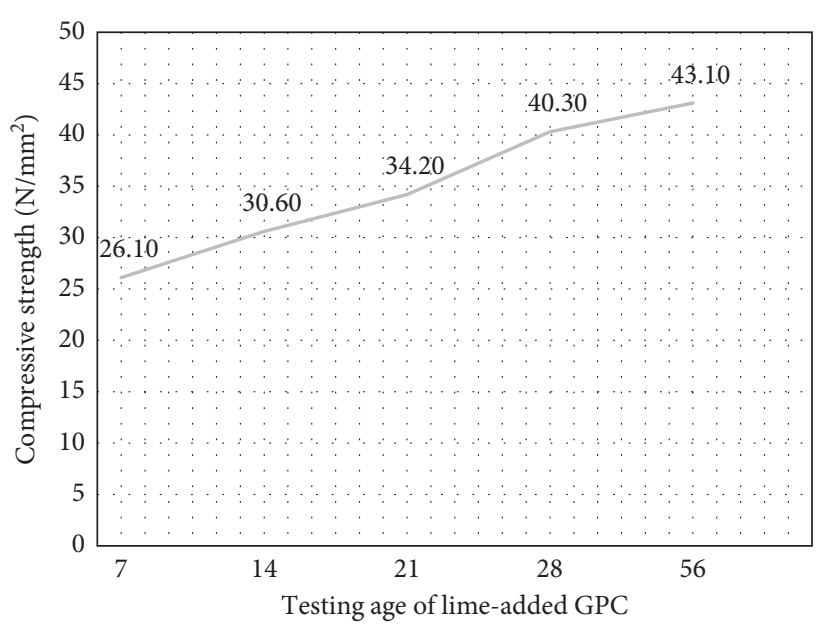

Figure 3: Cube cured at natural room temperature.

strength was achieved in 28 days. But, at 7 th day, the strength achieved was more than the designed strength. Thus, the optimum rest period observed here is 7 days for the project work being time bound.

4.3. GPC (M30) with 10\% Lime Addition Cured at Normal Room Temperature. The specimens were cast of size $150 \mathrm{~mm} \times 150 \mathrm{~mm} \times 150 \mathrm{~mm}$ of grade M30 having alkaline solution ratio as 2.5 and were cured at normal room temperature with an addition of $10 \%$ lime. These specimens were kept at normal room temperature for a rest period of 07,14 , 21, and 28 days after which the specimens were tested for compressive strength. The readings were recorded and listed, to know the effect on strength of GPC cured at normal room temperature.

Figure 3 represents the increase in the strength of geopolymer concrete of grade $\mathrm{M} 30+10 \%$ with the increase in the rest period at normal room temperature. The normal room temperature on an average was recorded as $28^{\circ} \mathrm{C}$ (temperature in the morning was recorded as $27^{\circ} \mathrm{C}$, and in the evening, it was recorded as $29^{\circ} \mathrm{C}$ ). The strength observed during the rest period of 7 days was achieved more than $70 \%$, unlike conventional cement concrete. The maximum compressive strength was achieved at 28th day which is more than the designed strength. Thus, geopolymer concrete of grade M30 with $10 \%$ lime addition by weight of fly ash does achieve strength more than desired at normal room temperature.

4.4. Effect of Varied Curing Temperature of GPC (M30) with 10\% Lime Addition. The specimens were cast of size $150 \mathrm{~mm} \times 150 \mathrm{~mm} \times 150 \mathrm{~mm}$ of grade M30 with addition of $10 \%$ of lime. The concrete cubes were cured at different elevated temperatures of $40^{\circ} \mathrm{C}, 50^{\circ} \mathrm{C}, 60^{\circ} \mathrm{C}, 70^{\circ} \mathrm{C}, 80^{\circ} \mathrm{C}, 90^{\circ} \mathrm{C}$, $100^{\circ} \mathrm{C}, 110^{\circ} \mathrm{C}$, and $120^{\circ} \mathrm{C}$ in an oven for 24 hours. After the completion of the defined curing time, these specimens were kept at normal room temperature for a rest period of 07 days after which the specimens were tested for compression on a compression testing machine of capacity $2000 \mathrm{KN}$. The readings were recorded and listed to study the effect of

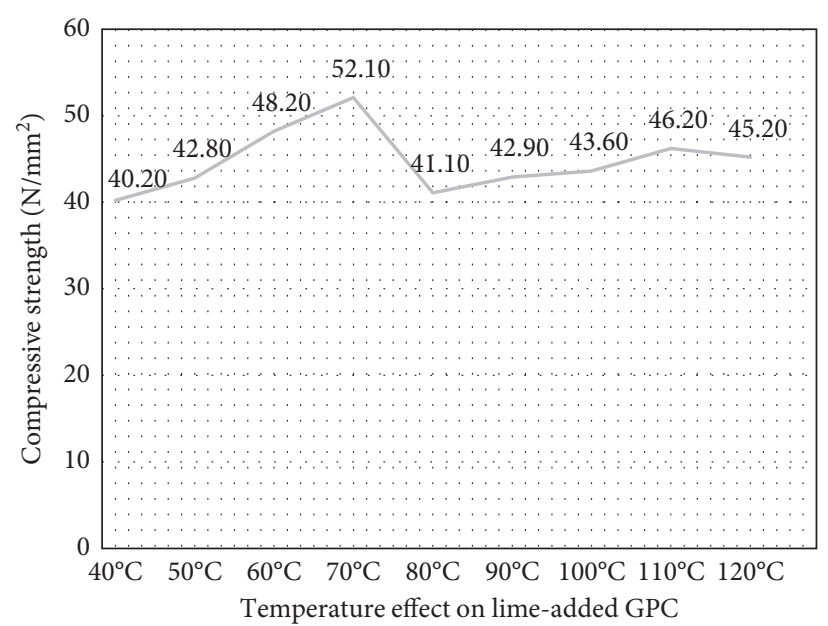

FIgURE 4: Effect of temperature on lime-based GPC.

varied curing temperature for geopolymer concrete with 10 percent of lime addition.

Figure 4 represents the variation in the strength of geopolymer concrete of grade M30 with the addition of $10 \%$ lime cured for 24 hours at varied temperatures. The rest period for the cured specimens was 07 days. The graph depicts the decrease in strength at higher temperatures. The maximum compressive strength was achieved with an addition of $10 \%$ of lime at $70^{\circ} \mathrm{C}$. Thus, the optimum temperature with $10 \%$ lime addition observed here is $70^{\circ} \mathrm{C}$.

\section{Conclusion}

(1) The compressive strength of geopolymer concrete of grade M30 goes on increasing with the addition of $5 \%$ and $10 \%$ of lime, where maximum can be achieved by the addition of $10 \%$ of lime.

(2) Addition of 15\%, 20\%, and $25 \%$ of lime in geopolymer concrete of grade M30 makes the concrete harsh which adversely affects its workability as well as its compressive strength.

(3) The compressive strength goes on increasing for an M30 grade of geopolymer concrete with $10 \%$ lime addition, as the rest period increases, where the maximum strength is achieved at the completion of 28 days of the rest period.

(4) The compressive strength of M30 grade of geopolymer concrete with the addition of $10 \%$ of lime goes on increasing with the increase in the curing temperature ranging from $40^{\circ} \mathrm{C}$ to $70^{\circ} \mathrm{C}$, where maximum can be achieved at $70^{\circ} \mathrm{C}$.

(5) When $5 \%$ of fly ash was replaced by lime by weight, the mixture observed was deficient in the binder, that is, fly ash, thereby decreasing the compressive strength of the geopolymer concrete making it necessary to add lime rather than replacing lime in the preparation of geopolymer concrete.

(6) compressive strength can also be achieved at higher curing temperatures ranging from $80^{\circ} \mathrm{C}$ to $120^{\circ} \mathrm{C}$ for 
M30 grade of geopolymer concrete with the addition of $10 \%$ lime.

(7) The compressive strength goes on increasing with the increase in the rest period of geopolymer concrete (M30) with the addition of $10 \%$ of lime when cured at normal room temperature, and the maximum compressive strength was achieved at the completion of 28 days of the rest period, thereby giving it a wide scope.

(8) The compressive strength achieved by grade M30 of geopolymer concrete cured at normal room temperature in a rest period of 7 days is higher than the compressive strength achieved by ordinary concrete for a similar rest period.

\section{Conflicts of Interest}

The authors declare that there are no conflicts of interest regarding the publication of this paper.

\section{References}

[1] S. V. Patankar, S. S. Jamkar, and Y. M. Ghugal, "Effect of water-to-geopolymer binder ratio on the production of fly ash based geopolymer concrete," in Proceedings of the International Conference on Recent Trends in Engineering and Technology (ICRTET'2013), Nashik, India, February 2013.

[2] D. Dutta and S. Ghosh, "Effect of lime stone dust on geopolymerisation and geopolymeric structure," International Journal of Emerging Technology and Advanced Engineering, vol. 2, no. 11, ISSN 2250-2459, 2012.

[3] S. L. Hake, R. M. Damgir, and S. V. Patankar, "State of artinvestigation of the method of curing on geopolymer concrete," IOSR Journal of Mechanical and Civil Engineering, vol. 12, no. 3, 2015.

[4] C. Namagga and R. A. Atadero, "Optimization of fly ash in concrete: high lime fly ash as a replacement for cement and filler material," in Proceedings of the World of Coal Ash (WOCA) Conference, Lexington, KY, USA, May 2009.

[5] B. Vijaya Rangan, "Geopolymer concrete for environmental protection," Indian Concrete Journal, vol. 88, no. 4, pp. 41-48, 2014.

[6] D. Bondar, "Geo-polymer concrete as a new type of sustainable construction materials," in Proceedings of the Third International Conference on Sustainable Construction Materials and Technologies, Kyoto, Japan, August 2015.

[7] P. R. Vora and U. V. Dave, "Parametric studies on compressive strength of geopolymer concrete," Procedia Engineering, vol. 51, pp. 210-219, 2013.

[8] N. N. Jain, S. L. Hake, and M. N. Shirsath, "Geopolymer concrete with lime addition at normal room temperature," International Journal of Research Publications in Engineering and Technology, vol. 2, no. 8, 2016.

[9] M. M. A. Abdullah, M. F. M. Tahir, K. Hussin et al., "Fly ash based lightweight geopolymer concrete using foaming agent technology," Revista De Chimie, vol. 66, no. 7, pp. 1001-1003, 2015.

[10] A. C. Ayachit, P. B. Nikam, S. N. Pise, A. D. Shah, and V. H. Pawar, "Mix design of fly-ash based geopolymer concrete," International Journal of Scientific and Research Publications, vol. 6, no. 2, pp. 2250-3153, 2016, ISSN 2250-3153.
[11] K. Ramujee, "Development of low calcium fly ash based geopolymer concrete," IACSIT International Journal of Engineering and Technology, vol. 6, no. 1, pp. 1-4, 2014.

[12] S. Ramasamy, K. Hussin, M. M. A. B. Abdullah et al., "Recent dissertations on kaolin based geopolymer materials," Reviews on Advanced Materials Science, vol. 42, no. 1, pp. 83-91, 2015.

[13] N. N. Jain, S. L. Hake, and M. N. Shirsath, "Percentage replacement of cement in geopolymer concrete," International Journal of New Technologies in Science and Engineering, vol. 3, no. 8, ISSN 2349-0780, 2016.

[14] B. H. Shinde and K. N. Kadam, "Properties of fly ash based geopolymer mortar," International Journal of Engineering Research \& Technology, vol. 4, no. 7, 2015.

[15] S. S. Jamkar, Y. M. Ghugal, and S. V. Patankar, "Effect of fly ash fineness on workability and compressive strength of geopolymer concrete," Indian Concrete Journal, vol. 87, no. 4, pp. 57-61, 2013.

[16] S. V. Patankar, Y. M. Ghugaland, and S. S. Jamkar, "Effect of concentration of sodium hydroxide and degree of heat curing on fly ash-based geopolymer mortar," Indian Journal of Materials Science, vol. 2014, Article ID 938789, 6 pages, 2014.

[17] A. M. M. Al Bakri, H. Kamarudin, I. K. Nizar et al., "Processing and characterization of fly ash-based geopolymers for lightweight concrete application," Revista De Chimie, vol. 64, no. 4, pp. 382-387, 2013.

[18] N. F. Shahedan, M. M. A. Abdullah, K. Hussin et al., "Characterization and design of alkali activated binder for coating application," Materiale Plastice, vol. 51, no. 3, pp. 258-262, 2014.

[19] K. Ramujee and M. Potharaju, "Development of mix design for low calcium based geopolymer concrete in low, medium and higher grades-Indian scenario," Journal of Civil Engineering and Technology, vol. 1, no. 1, pp. 15-25, 2013.

[20] M. I. Abdul Aleem and P. D. Arumairaj, "Optimum mix for the geopolymer concrete," Indian Journal of Science and Technology, vol. 5, no. 3, ISSN: 0974-6846, 2012.

[21] C. K. Madheswaran, G. Gnanasundar, and N. Gopalakrishnan, "Effect of molarity in geopolymer concrete," International Journal of Civil and Structural Engineering, vol. 4, no. 2, 2013.

[22] M. A. Javeed, M. Veerendra Kumar, and H. Narendra, "Studies on mix design of sustainable geopolymer concrete," International Journal of Innovative Research in Engineering \& Management, vol. 2, no. 4, ISSN: 2350-0557, 2015.

[23] M. A. Faris, M. M. A. Abdullah, A. V. Sandu et al., "Assessment of alkali activated geopolymer binders as an alternative of Portland cement," Materiale Plastice, vol. 54, no. 1, pp. 145-154, 2017.

[24] S. Das, A. Mohapatra, and A. K. Rath, "Geopolymer concrete-green concrete for the future-a review," International Journal of Civil Engineering Research, vol. 5, no. 1, pp. 21-28, 2014, ISSN 2278-3652.

[25] N. Nordin, M. M. A. Abdullah, M. F. M. Tahir, A. V. Sandu, and K. Hussin, "Utilization of fly ash waste as construction material," International Journal of Conservation Science, vol. 7, no. 1, pp. 161-166, 2016. 


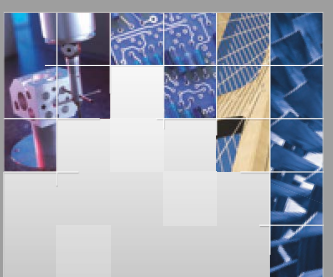

\section{Enfincering}
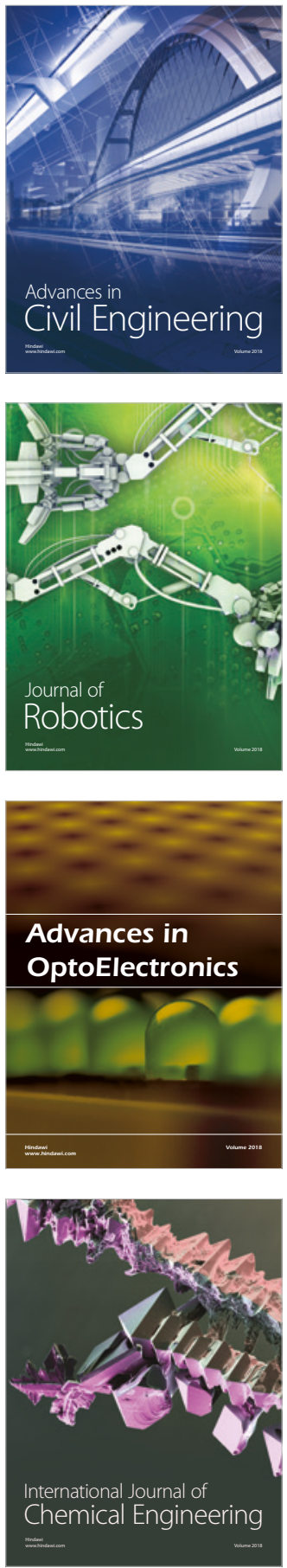

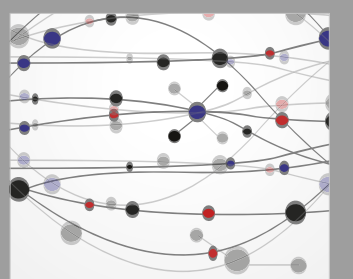

\section{Rotating \\ Machinery}

The Scientific World Journal

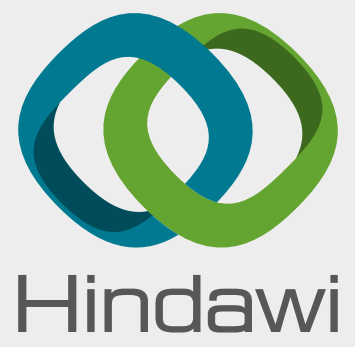

Submit your manuscripts at

www.hindawi.com
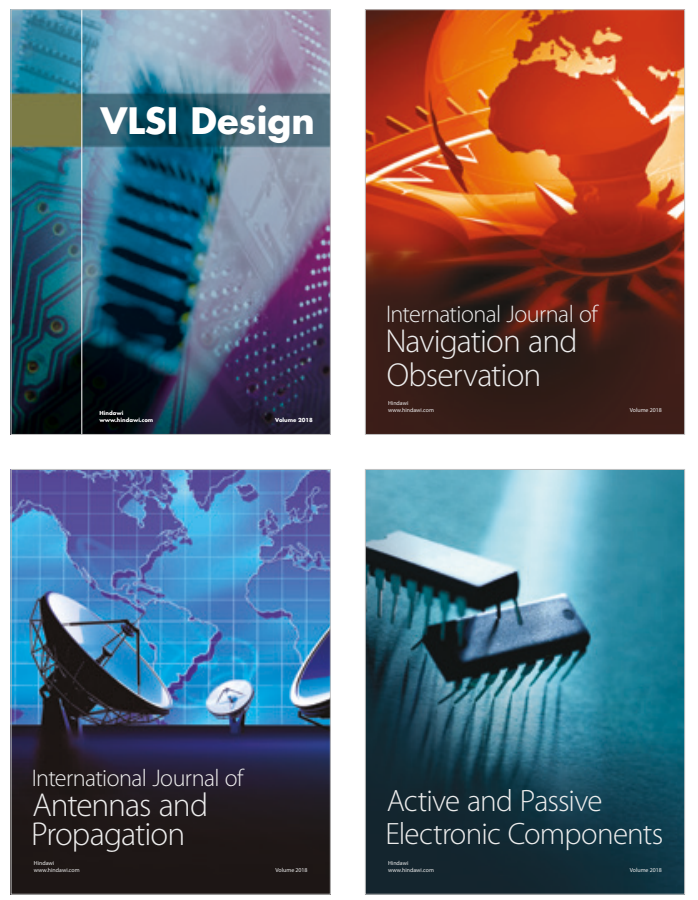
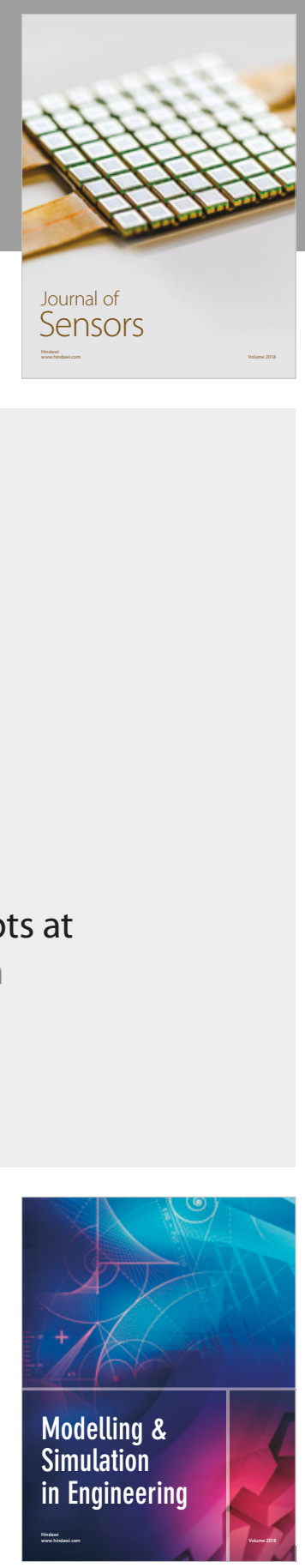

\section{Advances \\ Multimedia}
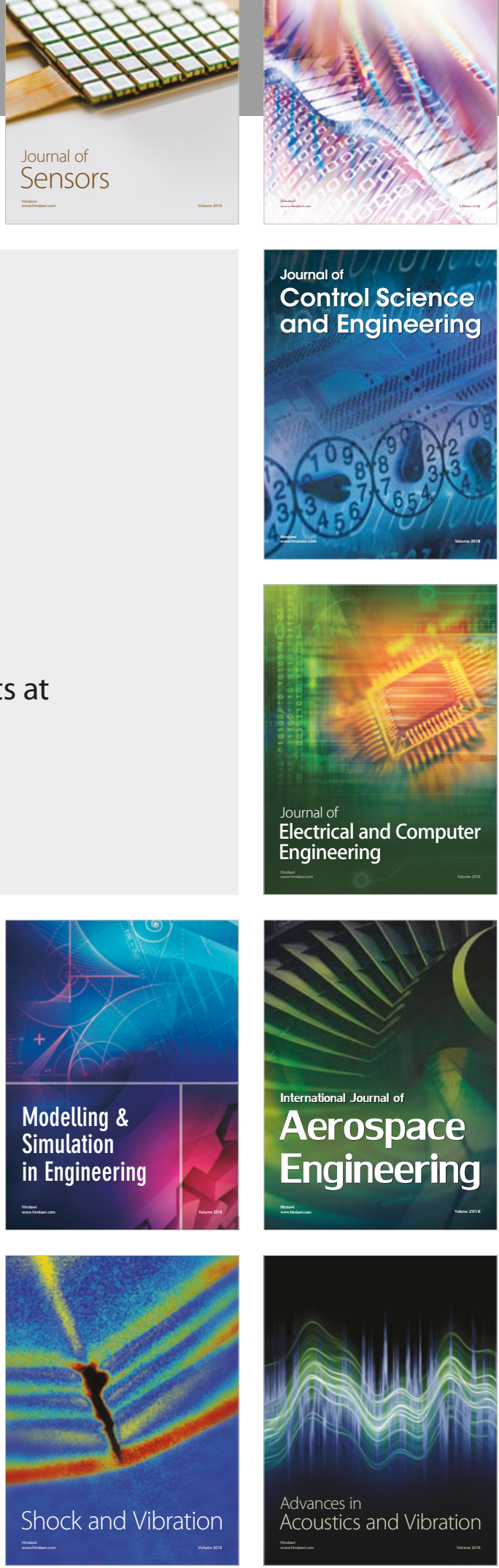